\title{
Roseovarius tolerans gen. nov., sp. nov., a budding bacterium with variable bacteriochlorophyll a production from hypersaline Ekho Lake
}

\author{
Matthias Labrenz, ${ }^{1}$ M. David Collins, ${ }^{2}$ Paul A. Lawson, ${ }^{2}$ Brian J. Tindall, ${ }^{3}$ \\ Peter Schumann ${ }^{4}$ and Peter Hirsch ${ }^{1}$
}

1 Institut für Allgemeine Mikrobiologie, Universităt Kiel, D-24118 Kiel Germany

2 Department of Microbiology, BBSRC Institute of Food Research, Reading Laboratory, Reading RG6 6BZ, UK

3 DSMZ - Deutsche Sammlung von Mikroorganismen und Zellkulturen $\mathrm{GmbH}$, D38124 Braunschweig, Germany

4 DSMZ - Deutsche Sammlung von Mikroorganismen und Zellkulturen $\mathrm{GmbH}$, D07745 Jena, Germany
Author for correspondence: Peter Hirsch. Tel: +49 4318804340 . Fax: +49 4318802194 . e-mail: phirsch@ifam.uni-kiel.de

\begin{abstract}
Eight Gram-negative, aerobic, pointed and budding bacteria were isolated from various depths of the hypersaline, heliothermal and meromictic Ekho Lake (Vestfold Hills, East Antarctica). The cells contained storage granules and daughter cells could be motile. Bacteriochlorophyll a was sometimes produced, but production was repressed by constant dim light. The strains tolerated a wide range of temperature, $\mathrm{pH}$, concentrations of artificial seawater and $\mathrm{NaCl}$, but had an absolute requirement for sodium ions. Glutamate was metabolized with and without an additional source of combined nitrogen. The dominant fatty acid was $C_{18: 1}$; other characteristic fatty acids were $C_{18: 2}, C_{12: 0}$ 2-OH, $C_{12: 1}$ 3$\mathrm{OH}, \mathrm{C}_{16: 1,} \mathrm{C}_{16: 0}$ and $\mathrm{C}_{18: 0}$. The main polar lipids were diphosphatidylglycerol, phosphatidylethanolamine, phosphatidylglycerol and phosphatidylcholine. The DNA G+C base composition was $62-64$ mol \%. 16S rRNA gene sequence comparisons showed that the isolates were phylogenetically close to the genera Antarctobacter, 'Marinosulfonomonas', Octadecabacter, Sagittula, Sulfitobacter and Roseobacter. Morphological, physiological and genotypic differences to these previously described and distinct genera support the description of a new genus and a new species, Roseovarius tolerans gen. nov., sp. nov. The type strain is EL-172 ${ }^{\top}$ (= DSM 11457').
\end{abstract}

Keywords: Roseovarius gen. nov., Roseovarius tolerans sp. nov., $\alpha$-Proteobacteria, bacteriochlorophyll $a$, Antarctica

\section{INTRODUCTION}

The ice-free area of the Vestfold Hills (East Antarctica) contains several lakes of various sizes which originated from fjords about 5000-6000 years ago. When the land subsequently rose due to the melting of the ice, the links of some lakes with the ocean were lost. Their initial connections with the ocean partly explain their salt composition and salinity. This origin may also have influenced the structure and types of their microbial communities (Franzmann et al., 1987; James et al., 1994). One such lake is the hypersaline, heliothermal and meromictic Ekho Lake, which contains

Abbreviations: ASW, artificial seawater; bchl, bacteriochlorophyll; MT, morphotypes; PTA, phosphotungstic acid.

The EMBL accession number for the $16 \mathrm{~S}$ rRNA sequence of strain EL-172 reported in this paper is $Y 11551$. many different environments throughout its depth profile. For this reason, the diversity of bacterial morphotypes (MT), total bacterial numbers and c.f.u. were studied there during two Antarctic summers ( $P$. Hirsch, J. Siebert \& H. R. Burton, unpublished results). A total of 135 prokaryotic and 52 eukaryotic MT was discovered. This unexpectedly high morphological diversity prompted the isolation of some 250 bacterial cultures from different depths of Ekho Lake and the initiation of a study of their taxonomic (phenotypic and phylogenetic) diversity. The isolation of four Gram-negative, aerobic, pointed and budding bacteria resulted in the description of Antarctobacter heliothermus gen. nov., sp. nov. (Labrenz et al., 1998). Prokaryotic, photosynthetic primary producers such as cyanobacteria were almost completely absent from the lake, but some aerobic, eubacterial isolates contained bacteriochlorophyll $a$ (bchl $a$ ). Also, several 
strains of eukaryotic photosynthetic primary producers (praseophytes with four flagella) were obtained in pure culture.

Obligately aerobic bchl $a$-containing bacteria have been found in the genera Roseobacter (Shiba, 1991), Roseococcus (Yurkov et al., 1994), Erythrobacter (Shiba \& Simidu, 1982), Erythromonas (Yurkov et al., 1997), Sandaracinobacter (Yurkov et al., 1997) and Porphyrobacter (Fuerst et al., 1993). This group covers a wide range of organisms from different geographical locations and with different physiological requirements. The relationship of bchl $a$-containing organisms (both anoxygenic phototrophs and obligately aerobic species) with organisms which do not contain bchl $a$ has led to speculations about the evolutionary origin of the class of Proteobacteria [which include purple non-sulfur bacteria (Woese, 1987)] together with differing interpretations of the role of bchl $a$ as a taxonomic marker. In the genus Roseobacter, for example, both Roseobacter denitrificans and Roseobacter litoralis (Shiba, 1991) produce bchl $a$, whereas Roseobacter algicola (Lafay et al., 1995) does not. Yurkov et al. (1997) considered the presence of bchl $a$ to be of such importance that, despite practically identical 16S rDNA sequence similarity ( $99.8 \%$ ), they considered Erythromonas ursincola and Blastomonas natatoria as members of different genera.

The present publication describes eight closely related bacterial isolates from Ekho Lake which can produce bchl $a$ under strictly aerobic conditions and represent a new genus and species.

\section{METHODS}

Water sampling, enrichment conditions and isolations. Water samples were taken aseptically from every metre of the Ekho Lake profile using a Kammerer sampler at the $42 \mathrm{~m}$ depth centre (Labrenz et al., 1998). Samples were stored over ice until used for the inoculation of enrichments or plates after returning to the Davis Station laboratory in the Vestfold Hills. Characteristics of these water samples and enrichment conditions are shown in Table 1. Isolation of pure cultures was achieved by several dilution transfers on the corresponding agar media. Pure cultures were kept as serial transfers on agar slants, or lyophilized, or deep-frozen at $-72^{\circ} \mathrm{C}$ in the growth medium.

Bacterial strains. For comparisons, the following type strains and other bacterial cultures were used: $R$. denitrificans $\left(\mathrm{DSM} 7001^{\mathrm{T}}\right), R$. litoralis (DSM 6996 $), R$. algicola (DSM $10251^{\mathrm{T}}$ ), A. heliothermus EL-219 ${ }^{\mathrm{T}}$ (= DSM $11445^{\mathrm{T}}$; Labrenz et al., 1998), $A$. heliothermus EL-165 (= DSM 11440), $A$. heliothermus EL-54 and $A$. heliothermus EL-185.

Media and culture conditions. Medium PYGV contained $\left(1^{-1}\right) 0.25 \mathrm{~g}$ each of Bacto peptone, Bacto yeast extract and glucose, as well as $20 \mathrm{ml}$ Hutner's basal salt solution (HBM; Cohen-Bazire et al., 1957) and $10 \mathrm{ml}$ Vitamin Solution no. 6 (Staley, 1968; Van Ert \& Staley, 1971). Media were solidified with $1.8 \%(\mathrm{w} / \mathrm{v})$ bacteriological agar (Gibco). Where needed, liquid and solid media were prepared to contain final concentrations of 25 or $40 \%$ (v/v) artificial seawater (ASW; Lyman \& Fleming, 1940). Before autoclaving, medium PYGV containing ASW was adjusted to $\mathrm{pH} 8 \cdot 5$; the final $\mathrm{pH}$ after autoclaving was $7 \cdot 2$. R2A agar (Difco) plus ASW was used to culture isolates for BIOLOG tests. Bacterial cultures for identification tests were incubated at $20^{\circ} \mathrm{C}$. Anaerobic cultivation in the light (at $4.0-21.5 \mu \mathrm{mol}$ photons $\mathrm{m}^{-2} \mathrm{~s}^{-1}$ ) occurred at $16^{\circ} \mathrm{C}$. Biomass for chemotaxonomic studies was grown in aerated liquid PYGV+ ASW at $20^{\circ} \mathrm{C}$ and harvested in the late exponential phase after 4-8 d.

Microscopy. Cell morphologies and aggregation behaviour were examined by phase-contrast light microscopy of young, liquid-grown cells on $2 \%$ water-agar-coated slides (Pfennig \& Wagener, 1986). Cells for transmission electron microscopy were washed with $0.5 \mathrm{M}$ ammonium acetate, negatively stained with $1 \%$ phosphotungstic acid (PTA) and observed with a Philips EM 300 electron microscope at $80 \mathrm{kV}$.

For ultrathin sectioning, young cells were fixed with glutaraldehyde $(3 \%)$ for $3 \mathrm{~h}$. After washing in Sörensen buffer $(0 \cdot 15 \mathrm{M}, \mathrm{pH} 7 \cdot 5)$, post-fixation was carried out with $\mathrm{OsO}_{4}$

Table 1. Characteristics of the original 1989/1990 Ekho Lake samples from which the isolates were obtained and the enrichment conditions

\begin{tabular}{|c|c|c|c|c|c|c|c|}
\hline \multirow[t]{2}{*}{ Isolate } & \multirow{2}{*}{$\begin{array}{c}\text { Depth } \\
\text { (m) }\end{array}$} & \multirow{2}{*}{$\begin{array}{c}\text { Salinity } \\
(\%)\end{array}$} & \multirow{2}{*}{$\begin{array}{c}\text { Temperature } \\
\left({ }^{\circ} \mathrm{C}\right)\end{array}$} & \multirow[t]{2}{*}{$\mathbf{p H}$} & \multicolumn{3}{|c|}{ Enrichment conditions } \\
\hline & & & & & Medium & $\begin{array}{c}\text { Temperature } \\
\left({ }^{\circ} \mathrm{C}\right)\end{array}$ & $\begin{array}{c}\text { Light } \\
\left(\mu \mathrm{mol} \mathrm{m}^{-2} \mathrm{~s}^{-1}\right)\end{array}$ \\
\hline EL-171 & 6 & 63 & $12 \cdot 9$ & $8 \cdot 30$ & PYGV* & 15 & $4 \cdot 1$ \\
\hline EL-78 & 6 & 65 & $14 \cdot 8$ & $8 \cdot 22$ & PYGV* & 15 & Dark \\
\hline EL-164 & 9 & 72 & $14 \cdot 6$ & $8 \cdot 16$ & $50 \mathrm{ml}$ sample $+2.5 \mathrm{mg} \mathrm{YE} \dagger$ & 15 & $4 \cdot 1$ \\
\hline EL-172T & 10 & 73 & $14 \cdot 9$ & $8 \cdot 16$ & PYGV* & 15 & $4 \cdot 1$ \\
\hline EL-83 & 14 & 73 & $16 \cdot 0$ & $8 \cdot 01$ & $\mathrm{PYGV}+67 \%$ ASW & 4 & $4 \cdot 1$ \\
\hline EL-52 & 14 & 75 & $16 \cdot 0$ & $8 \cdot 01$ & PYGV $+69 \%$ ASW & 4 & $4 \cdot 1$ \\
\hline EL-90 & 16 & 82 & $17 \cdot 0$ & $7 \cdot 66$ & Sabouraud dextrose agar + & 15 & $4 \cdot 1$ \\
\hline EL-222 & 22 & 142 & $15 \cdot 5$ & 6.98 & PYGV $+130 \%$ ASW & 15 & $4 \cdot 1$ \\
\hline
\end{tabular}

* Medium PYGV (Staley, 1968), prepared with Ekho Lake water of $72 \%$ salinity.

$\uparrow$ YE, Bacto yeast extract.

$\$$ Prepared with Ekho Lake water of $72 \%$ salinity. 
$(1 \%)$ in the same buffer for $3 \mathrm{~h}$. Agar-embedded cells were then dehydrated by a graded series of ethanol, followed by embedding in ERL (Spurr) and polymerization at $70^{\circ} \mathrm{C}$ for $8 \mathrm{~h}$. Ultrathin sections were cut with a Reichert Ultratome S with a diamond knife. Sections were post-stained with uranyl acetate and lead citrate.

Physiological and biochemical characterization. All physiological tests were performed at $20^{\circ} \mathrm{C}$. Gram-staining was done with $24 \mathrm{~h}$ cultures (Skerman, 1967). Catalase production was detected with $5 \% \mathrm{H}_{2} \mathrm{O}_{2}$. Peroxidase and cytochrome oxidase activities were tested as previously described (Drews, 1974; Kreisel \& Schauer, 1987). DNA hydrolysis was indicated by clear zones around colonies on Bacto DNase Test Agar (Difco) plus ASW. Amylase activity and the relation to oxygen were studied as previously described (Smibert \& Krieg, 1994). Motility was examined in hanging drop preparations. The ability to grow under various physical and chemical conditions was investigated in liquid media. Osmotolerance was studied in PYGV prepared with $0,10,20-100,130$ and $150 \%$ ASW after $14 \mathrm{~d}$ incubation. Since a concentration of $150 \%$ ASW did not easily dissolve, $20 \% \mathrm{NaCl}$ was added to $130 \%$ ASW to reach the required salinity. $\mathrm{NaCl}$ tolerance was determined in $\mathrm{PYGV}$ prepared with $0 \cdot 0,1 \cdot 0.4 \cdot 0,6 \cdot 0,8 \cdot 0,10 \cdot 0,13 \cdot 0$ and $15 \cdot 0 \%$ $\mathrm{NaCl}$ after $14 \mathrm{~d}$ incubation. The ability to grow between pH 5.3 and 9.0 , and at temperatures between 3.0 and $43.5^{\circ} \mathrm{C}$, was also tested in PYGV + ASW medium and evaluated by protein determination (Bradford, 1976) of triplicate cultures. The requirement(s) for the following vitamins were tested in six combinations, each lacking one vitamin of Vitamin Solution no. 6 : biotin, thiamin hydrochloride, nicotinic acid, sodium pantothenate or vitamin $\mathrm{B}_{12}$. In these experiments casein hydrolysate (vitamin-free; Merck) was used instead of Bacto peptone and Bacto yeast extract. Triplicate results were recorded after three serial transfers in the corresponding test media. Requirements for $\mathrm{Na}^{+}, \mathrm{K}^{+}, \mathrm{Mg}^{2+}, \mathrm{Ca}^{2+}, \mathrm{Cl}^{-}$or $\mathrm{SO}_{4}^{2-}$ were studied in PYGV + ASW where $\mathrm{Na}^{+}$was exchanged with $\mathrm{K}^{+}, \mathrm{Mg}^{2+}$ with $\mathrm{Ca}^{2+}, \mathrm{Cl}^{-}$with $\mathrm{SO}_{4}^{2-}$ and vice versa. Susceptibility to antibiotics was determined with bioDiscs (bioMérieux) and the results were recorded after $4 \mathrm{~d}$. The aerobic reduction of nitrate to nitrite was tested after $14 \mathrm{~d}$ and the anaerobic reduction of nitrate to nitrite or $\mathrm{N}_{2}$ was assessed after 3 weeks of incubation. In both cases, PYGV + ASW containing $5 \mathrm{mM} \mathrm{NaNO}$ was used. Anaerobic growth was examined in PYGV + ASW which was modified to contain $\left(1^{-1}\right) 0.1 \mathrm{~g}$ glucose, $0 \cdot 1 \mathrm{~g}$ acetate, $0 \cdot 1 \mathrm{~g}$ glutamate and $0.5 \mathrm{~g}$ Tris pure (Biomol). The medium was saturated with $\mathrm{N}_{2}$ for $20 \mathrm{~min}$, and $20 \mathrm{ml}$ was distributed in $100 \mathrm{ml}$ serum bottles. To test for photolithoautotrophic or photoorganotrophic growth, cultures were incubated under an atmosphere of $\mathrm{H}_{2} / \mathrm{CO}_{2}(80: 20 ; 0.9$ bar $)$ and at light intensities of $4 \cdot 0-21.5 \mu \mathrm{mol}$ photons $\mathrm{m}^{-2} \mathrm{~s}^{-1}$. Production of poly- $\beta$-hydroxybutyrate was followed in PHBA medium, which was PYGV + ASW modified to contain $\left(1^{-1}\right) 20 \mathrm{ml}$ HBM, $10 \mathrm{ml}$ Vitamin Solution no. 6, 0.1 g Bacto yeast extract and $2.0 \mathrm{~g}$ succinate as described previously (Smibert $\&$ Krieg, 1994). Methyl red and Voges-Proskauer tests were performed in PYGV + ASW containing 0.2\% (w/v) Bacto peptone and $0.2 \%(\mathrm{w} / \mathrm{v})$ glucose. $\mathrm{H}_{2} \mathrm{~S}$ and indole production were tested with the sulfide indole motility medium (Merck) plus ASW. Indole was detected with Kóvacs reagent.

To study the aerobic dissimilation of 95 carbon sources with the BIOLOG system, Microlog software, a Tandon computer and a microplate photometer (Molecular Devices) were used. Standard suspensions were prepared from growth on R2A agar after $3-4 \mathrm{~d}$ at $20^{\circ} \mathrm{C}$ and test evaluation was after 4,24 and $48 \mathrm{~h}$; the results were reproducible. Additionally, $\mathrm{C}$ source utilization was studied in a minimal medium containing $\left(1^{-1}\right) 20 \mathrm{ml}$ HBM, $10 \mathrm{ml}$ Vitamin Solution no. 6, 0.02 g Bacto yeast extract and $0.25 \mathrm{~g} \mathrm{NH}_{4} \mathrm{NO}_{3}$. The following $\mathrm{C}$ sources were tested at $0.2 \%(\mathrm{w} / \mathrm{v})$ : acetate, pyruvate, malate, citrate, succinate, butyrate, glutamate, $\alpha$ $\mathrm{D}$-glucose, methanol and methanesulfonic acid. Degradation of the following substrates was tested with the basal medium PYV + ASW (i.e. lacking glucose): $0 \cdot 2 \%(\mathrm{w} / \mathrm{v})$ starch, $0 \cdot 4 \%$ gelatin, $1 \%$ Tween 80 , or $0.75 \%$ alginate. Production of bchl $a$ was followed in suspensions of cells grown in PYGV + ASW and analysed as described (Shiba \& Simidu, 1982). Methanolic extracts were also studied with a Beckman DU-600 spectrophotometer and by TLC as previously described (Lafay et al., 1995). Tests were performed with cells grown in constant light at $4 \cdot 0-21.5 \mu \mathrm{mol}$ photons $\mathrm{m}^{-2} \mathrm{~s}^{-1}$ or with cells grown in the dark.

Chemotaxonomy. Fatty acid methyl esters were analysed in $20 \mathrm{mg}$ freeze-dried biomass and using methods which allowed selective hydrolysis of ester- and amide-linked fatty acids. Fatty acid methyl esters were analysed in two different ways. The first method was GC (GC-14A; Shimadzu) using a $0.2 \mathrm{~mm} \times 25 \mathrm{~m}$ non-polar capillary column and flameionization detection. The running conditions were as follows: injector and detector port temperature, $300^{\circ} \mathrm{C}$; inlet pressure, $80 \mathrm{kPa}$; split ratio, $50: 1$; injection volume, $1 \mu \mathrm{l}$; and a temperature programme of $130-310^{\circ} \mathrm{C}$ at a rate of $4{ }^{\circ} \mathrm{C} \mathrm{min}{ }^{-1}$. Hydrogen was the carrier gas. The fatty acids were identified by converting retention times to equivalent chain-length data (Sasser, 1990). Saturated $C_{10}-C_{30}$ fatty acid methyl esters were used as standards. Fatty acid methyl esters that could not be identified on the basis of their retention times were analysed by GC-MS using a model GCMS-QP2000 instrument (Shimadzu) under previously described GC conditions (Groth et al., 1996). Respiratory lipoquinones and polar lipids were extracted from $100 \mathrm{mg}$ freeze-dried material using the two-stage method and analysed as described previously (Tindall, 1990a, b). Diamino acids of cell walls were separated by one-dimensional TLC on cellulose plates using the solvent system of Rhuland $e t$ al. (1955).

Determination of DNA $\mathbf{G}+\mathrm{C}$ composition. DNA $\mathrm{G}+\mathrm{C}$ contents were analysed by HPLC (Mesbah et al., 1989). The HPLC equipment (Pharmacia-LKB) had a Spherisorb ODS $\mathrm{II} \mathrm{C}_{18}$ column $(5 \mu \mathrm{m} ; 4 \times 250 \mathrm{~mm}$; Bischoff). Escherichia coli strain B type VIII DNA (Sigma) and phage lambda DNA from $E$. coli host strain GM 119 (Sigma) were used as standards.

DNA-DNA hybridization. Dot-blot hybridization experiments were carried out with the DIG DNA Labelling and Detection kit from Boehringer Mannheim according to the manufacturer's instructions. DNA probes were prepared from EL-90, EL-164, EL-171, EL-172 ${ }^{\mathrm{T}}$, EL-222 and $A$. heliothermus EL-219 ${ }^{\mathrm{T}}$. Hybridization occurred against chromosomal DNA from the Ekho Lake strains, $A$. heliothermus and against $R$. denitrificans. The stringency of 70 and $75 \%$ was calculated according to Sambrook et al. (1989).

165 rRNA gene sequence determination and analysis of sequence data. 16S rRNA gene fragments were generated by PCR as previously described (Hudson et al., 1993). A large fragment of the 16S rRNA gene was amplified from DNA by PCR using universal primers pA (positions 8-28, E. coli numbering) and $\mathrm{pH}^{*}$ (positions 1542-1522). The amplified product was purified with a QIAquick PCR Purification kit 
(Qiagen) and sequenced directly using primers to conserved regions of the rRNA. Sequencing was performed using a PRISM Taq DyeDeoxy Terminator Cycle Sequencing kit (Applied Biosystems) and an automatic DNA sequencer (model 373A; Applied Biosystems). To establish the closest relatives of the eight Ekho Lake strains, preliminary searches in the EMBL database were performed with the FASTA program (Pearson \& Lipman, 1988). Sequences closely related to those of the Ekho Lake strains were retrieved from the EMBL database and aligned with the newly determined sequences using the PILEUP program (Devereux et al., 1984). The rRNA alignment was corrected manually and approximately 100 bases at the $5^{\prime}$ end of the molecule were omitted from further analysis because of alignment uncertainties due to the highly variable region V1. Percentage sequence similarities were calculated and corrected for substitution rates using the parameters of Jukes \& Cantor (1969). A phylogenetic tree was constructed according to the neighbour-joining method (Saitou \& Nei, 1987) with the NEIGHBOR program. For this analysis, the following additional taxa, listed by genera and accession number, were included: Rhodomicrobium vannielii (M34127), 'Methylosulfonomonas methylovora' (U62893), Rhodobium marinum (D30790), Rhodobium orientis (D30792), Rhodospirillum salexigens (M59070), Rhodovulum euryhalinum (D13479), Rhodovulum sulfidophilum (U55277), Rhodovulum adriaticum (D16418), Rhodobacter blasticus (D16429), Rhodobacter capsulatus (D16428), Rhodobacter sphaeroides (D16425), Rhodobacter veldkampii (D16421), Rhodospirillum rubrum (D30778), Rhodospirillum photometricum (D30777), Rhodospirillum fulvum (D14433), Rhodospirillum molischianum (M59067), Rhodospirillum salinarum (M59069), Rhodospirillum sodomense (M59072), Rhodopila globiformis (M59066), Rhodoplanes roseus (D25313), Blastochloris viridis (D25314), Rhodopseudomonas palustris (D25312) and Rhodopseudomonas acidophila (M34128). The stability of the groupings was estimated by bootstrap analysis (500 replications) using the programs of the PHYLIP package (Felsenstein, 1989).

\section{RESULTS}

\section{Isolation of bacteria, morphology and motility}

Six different enrichment procedures yielded pure cultures with similar morphology; eight of these were obtained from Ekho Lake samples from 6, 9, 10, 14, 16 and $22 \mathrm{~m}$ (Table 1). These isolates are referred to as EL-52, EL-78, EL-83, EL-90, EL-164, EL-171, EL$172^{\mathrm{T}}$ and EL-222. They were all Gram-negative rods with one or both cell poles pointed (Figs 1, 2b). Motility was observed in PHBA medium. Small daughter cells showed predominantly tumbling motion and only rarely a directed movement; flagella were not found. Cell growth appeared to be monopolar since one cell end was usually narrower and shorter, which indicated a budding process (Fig. 2a, b; Hirsch, 1974). All eight isolates contained electron-transparent poly$\beta$-hydroxybutyrate granules. Their cell sizes varied $(0 \cdot 7-1.0 \times 1 \cdot 1-2.2 \mu \mathrm{m})$.

\section{Culture and growth characteristics}

Aerobic growth was visible after $3-5 \mathrm{~d}$ at $20^{\circ} \mathrm{C}$ on medium PYGV $+25 \%$ (or $40 \%$ ) ASW or on R2A agar with ASW. Colonies were circular, smooth,

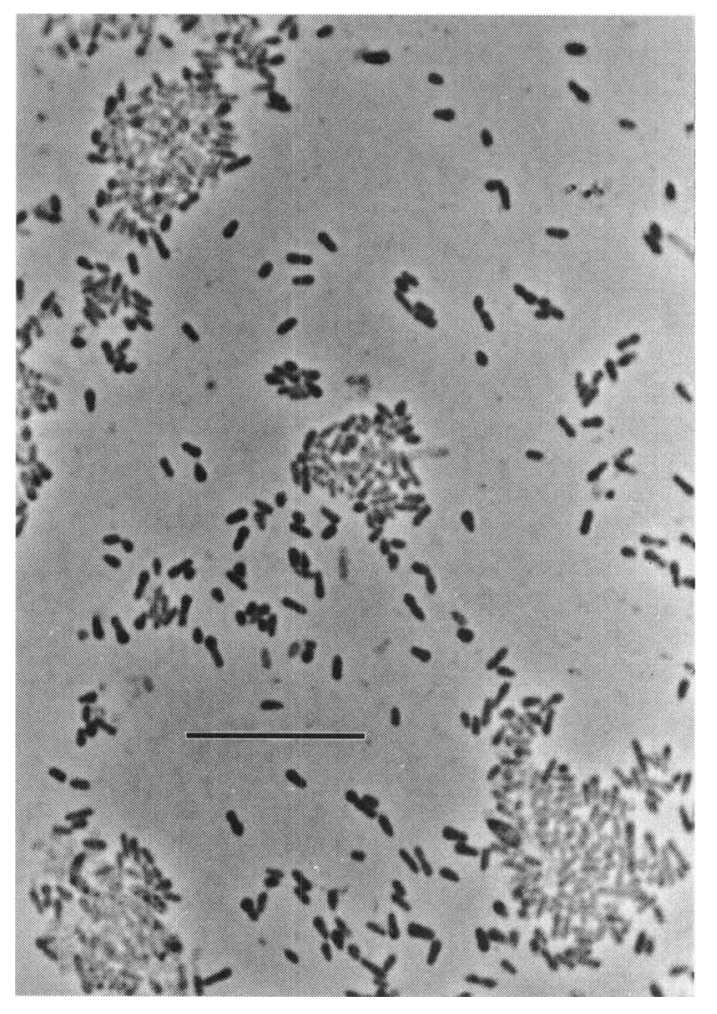

Fig. 1. Phase-contrast light micrograph of strain $E L-172^{\top}$ on an agar-coated slide (Pfennig \& Wagener, 1986). Bar, $10 \mu \mathrm{m}$.

convex, 1-2 $\mathrm{mm}$ in diameter and red (EL-78, EL$172^{\mathrm{T}}$ ), pink (EL-83), beige to light red (EL-90, EL171), beige or whitish-beige (EL-52, EL-164, EL-222). The temperature range for growth was below 3 and below $43.5^{\circ} \mathrm{C}$. Optimal growth occurred between 8.5 and $33.5^{\circ} \mathrm{C}$ and at $\mathrm{pH}$ values of 6.9 to $>9.0$. The eight isolates had an absolute requirement for $\mathrm{Na}^{+}$; the other cations and anions tested could all be replaced as indicated in Methods. The EL isolates had a weak requirement for thiamin, nicotinic acid and possibly biotin. Pantothenate was not required and vitamin $B_{12}$ stimulated most isolates except for EL-164 and EL222. Osmotolerance ranged from below 10 to over $150 \%$ ASW, with an optimum between 10 and $130 \%$ ASW. The $\mathrm{NaCl}$ tolerance was $<1.0$ to $10.0 \%$, with an optimum between 1.0 and $8.0 \% \mathrm{NaCl}$.

\section{Physiological and biochemical characteristics}

Phenotypic characteristics that differentiated EL-172 a representative strain of this group, from $A$. heliothermus, $R$. algicola, $R$. denitrificans, $R$. litoralis or from Sulfitobacter pontiacus (Sorokin, 1995) are listed in Table 2. All eight strains of the unknown bacterium exhibited peroxidase, catalase and a weak cytochrome oxidase activity. They did not produce acetoin or acids from glucose. They were susceptible to chloramphenicol $(30 \mu \mathrm{g})$ and streptomycin $(10 \mu \mathrm{g})$, but not to polymyxin B (300 U). Strains EL-164 and EL-222 


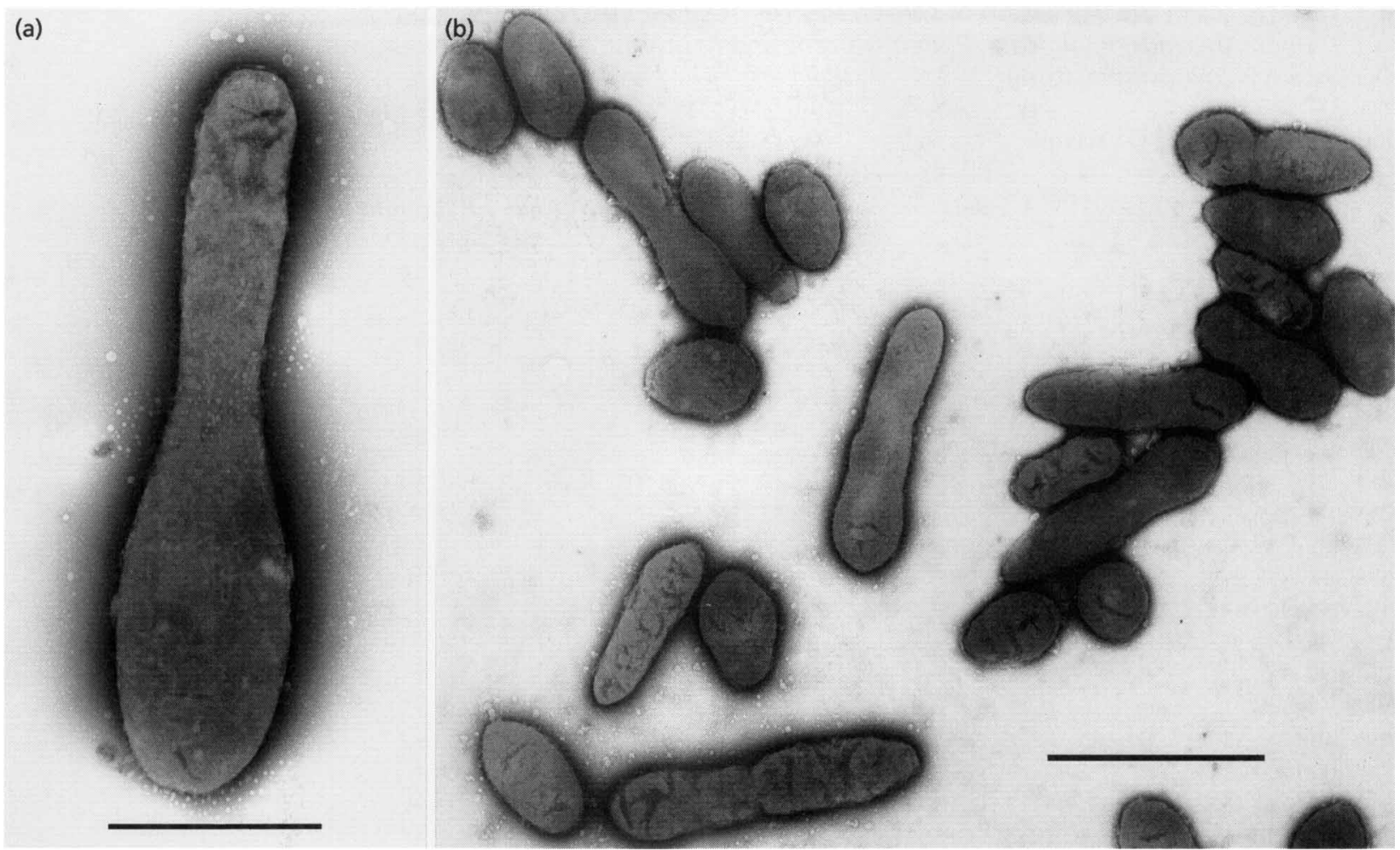

Fig. 2. (a) Cell of EL-171 shows monopolar growth. Bar, $1 \mu \mathrm{m}$. (b) Electron micrograph of cells of strain EL-90 negatively stained with PTA. Bar, $2 \mu \mathrm{m}$.

Table 2. Comparison of isolate EL-172 ${ }^{\top}$ with literature data for $A$. heliothermus EL-219 ${ }^{\top}$ and the type strains of $R$. algicola, $R$. denitrificans, $R$. litoralis, Sulfitobacter pontiacus and Sagittula stellata

ND, Not determined; w, weak reaction.

\begin{tabular}{|c|c|c|c|c|c|c|c|}
\hline Characteristic & EL-172 ${ }^{\mathrm{T}}$ & A. heliothermus & R. algicola & $\boldsymbol{R}$. denitrificans & R. litoralis & $\begin{array}{c}\text { Sulfitobacter } \\
\text { pontiacus }\end{array}$ & $\begin{array}{c}\text { Sagitulla } \\
\text { stellata }\end{array}$ \\
\hline Cell shape: rods & + & + & Ovoid & Ovoid & Ovoid & + & + \\
\hline Rosettes formed & - & + & - & - & - & + & + \\
\hline Colony colour & Red & Brown-yellow & Brown-beige & Red & Red & Colourless & Cream \\
\hline Bchl $a$ & + & - & - & + & + & - & - \\
\hline Temperature optimum $\left({ }^{\circ} \mathrm{C}\right)$ & $8 \cdot 5-33 \cdot 5$ & $16-20$ & $25-30$ & $20-30$ & $20-30$ & $22-25$ & 30 \\
\hline $\mathrm{NaCl}$ optimum (\%) & $1 \cdot 0-8 \cdot 0$ & $2 \cdot 0$ & ND & ND & ND & $2 \cdot 0-2 \cdot 5$ & $\mathrm{ND}^{*}$ \\
\hline pH optimum & $6 \cdot 2->9 \cdot 0$ & $7 \cdot 0-8 \cdot 0$ & 7.5 & $7 \cdot 0-8 \cdot 0$ & $7 \cdot 0-8 \cdot 0$ & $7 \cdot 3-7 \cdot 5$ & 7.5 \\
\hline \multicolumn{8}{|l|}{$\mathrm{NO}_{3}^{-}$reduction: } \\
\hline Dissimilatory & - & + & - & + & - & ND & - \\
\hline Assimilatory & - & + & - & + & ND & $\mathrm{ND}$ & - \\
\hline Indole production & - & - & - & + & - & - & - \\
\hline Nicotinic acid requirement & w & + & - & + & + & ND & - \\
\hline Vitamin $B_{12}$ requirement & + & - & ND & - & ND & ND & ND \\
\hline \multicolumn{8}{|l|}{ C source: } \\
\hline Butyrate & w & + & $-\dagger$ & - & - & + & + \\
\hline Citrate & - & + & + & + & + & - & + \\
\hline$\alpha$-D-Glucose & - & + & + & + & + & $\mathrm{ND}$ & + \\
\hline Gelatin hydrolysis & - & + & + & + & + & - & - \\
\hline DNA hydrolysis & - & + & - & ND & $\mathrm{ND}$ & - & ND \\
\hline$C_{18: 2}$ fatty acid & + & - & + & + & + & ND & - \\
\hline $\mathrm{G}+\mathrm{C}$ content $(\mathrm{mol} \%)$ & $63 \cdot 3-63 \cdot 4$ & $62 \cdot 6-62 \cdot 8$ & $64 \cdot 0-65 \cdot 0$ & $59 \cdot 1-60 \cdot 1$ & $56 \cdot 3-58 \cdot 1$ & $61 \cdot 7-62 \cdot 5$ & 65 \\
\hline Phosphatidylcholine & + & + & + & + & - & ND & ND \\
\hline Diphosphatidylglycerol & + & - & + & + & + & ND & ND \\
\hline Phosphatidylethanolamine & + & - & + & - & - & ND & ND \\
\hline Unknown phospholipid & + & + & - & + & + & ND & ND \\
\hline
\end{tabular}

* Not determined, but requires $\mathrm{NaCl}$ (Gonzalez et al., 1997).

$\dagger$ Positive in the present study. 
Table 3. Differences in the utilization of carbon sources of strain EL-172 ${ }^{\top}$ to the type strains of $A$. heliothermus, $R$. algicola, $R$. denitrificans and $R$. litoralis as detected with the BIOLOG system in the present study

+ , Positive; - , negative; v, variable.

\begin{tabular}{|c|c|c|c|c|c|}
\hline Substrate & EL-172 ${ }^{\mathrm{T}}$ & A. heliothermus & R. algicola & $R$. denitrificans & R. litoralis \\
\hline Glycogen & - & - & + & - & - \\
\hline Tween 40 & $\mathrm{v}$ & - & + & $\mathrm{v}$ & + \\
\hline Tween 80 & - & - & - & + & + \\
\hline L-Arabinose & - & - & + & + & $\mathrm{v}$ \\
\hline Cellobiose & $\mathrm{v}$ & - & + & - & - \\
\hline Psicose & - & - & + & + & + \\
\hline Xylitol & - & $\mathbf{v}$ & - & + & + \\
\hline cis-Aconitic acid & - & - & - & $\mathrm{v}$ & + \\
\hline D-Gluconic acid & - & - & $\mathrm{v}$ & + & + \\
\hline D-Glucosaminic acid & $\mathrm{v}$ & - & $\mathrm{V}$ & + & + \\
\hline D-Glucuronic acid & - & - & - & + & + \\
\hline Malonic acid & - & - & + & + & - \\
\hline Quinic acid & - & - & - & + & + \\
\hline D-Saccharic acid & - & - & - & + & + \\
\hline Alanine amide & - & - & + & $\mathrm{v}$ & - \\
\hline L-Asparagine & $\mathbf{v}$ & - & + & $\mathrm{v}$ & + \\
\hline L-Aspartic acid & - & - & - & $\mathrm{v}$ & + \\
\hline L-Glutamic acid & - & - & - & + & + \\
\hline Glycyl-L-aspartic acid & - & - & - & + & + \\
\hline D-Serine & - & - & - & + & + \\
\hline L-Serine & - & - & - & + & + \\
\hline Inosine & + & - & + & + & + \\
\hline Thymidine & - & - & $\mathrm{v}$ & $\mathrm{v}$ & + \\
\hline 2,3-Butanediol & - & - & $\mathbf{v}$ & - & + \\
\hline Glucose-1-phosphate & - & - & - & $\mathrm{V}$ & + \\
\hline
\end{tabular}

were not susceptible to penicillin $\mathrm{G}(10 \mathrm{U})$, and EL-83, EL-90 and EL-222 were not susceptible to tetracycline $(30 \mu \mathrm{g})$. The eight strains were not capable of assimilatory or dissimilatory nitrate reduction. Neither sulfide nor indole were produced. Only EL-52 hydrolysed Tween 80, and EL-83 had DNase activity. None of the strains hydrolysed gelatin or starch. In the presence of available nitrogen, they utilized succinate, butyrate, glutamate, acetate, pyruvate and malate, but not methanol, methanesulfonic acid, citrate or $\alpha$-Dglucose. In the absence of other $\mathrm{N}$ sources, glutamate was utilized as a sole $\mathrm{C}$ and $\mathrm{N}$ source. Slight growth was observed with acetate, pyruvate, malate, succinate and possibly butyrate without any added nitrogen source.

Differences in the metabolism of carbon compounds as revealed with the BIOLOG system are shown in Table 3 . The eight test strains, $A$. heliothermus and the Roseobacter species metabolized $N$-acetyl-D-galactosamine, $N$-acetylglucosamine, adonitol, D-arabitol, $i$ erythritol, D-fructose, L-fucose, D-galactose, gentiobiose, $\alpha$-D-glucose, $\alpha$-lactose, $\alpha$-D-lactose/lactulose, maltose, D-mannitol, D-mannose, D-melibiose, D-raffinose, L-rhamnose, D-sorbitol, sucrose, D-trehalose, turanose, acetic acid, citric acid, itaconic acid, pro- pionic acid, glucuronamide, L-alanyl-glycine and uridine. However, they did not metabolize $\alpha$-cyclodextrin, dextrin, methyl $\beta$-D-glucoside, methyl pyruvate, monomethylsuccinate, formic acid, D-galactonic acid lactone, D-galacturonic acid, $\alpha$-hydroxybutyric acid, $\beta$ hydroxybutyric acid, $\gamma$-hydroxybutyric acid, $p$ hydroxyphenylacetic acid, $\alpha$-ketobutyric acid, $\alpha$-ketoglutaric acid, $\alpha$-ketovaleric acid, DL-lactic acid, sebacic acid, succinic acid, bromosuccinic acid, succinamic acid, D-alanine, L-alanine, glycyl-L-glutamic acid, Lhistidine, hydroxy-L-proline, L-leucine, L-ornithine, Lphenylalanine, L-proline, L-pyroglutamic acid, L-threonine, DL-carnitine, $\gamma$-aminobutyric acid, urocanic acid, phenylethylamine, putrescine, 2-aminoethanol, glycerol, glucose-6-phosphate or DL- $\alpha$-glycerophosphate. They did not grow anaerobically and photolithoautotrophically with $\mathrm{H}_{2} / \mathrm{CO}_{2}(80: 20)$ in the gas phase, and they did not grow photoorganotrophically. Strain EL-222 grew microaerophilically.

Bchl $a$ was found in cell suspensions or methanolic extracts of EL-78, EL-83, EL-171 and EL-172 ${ }^{\mathrm{T}}$ when grown in the dark. Under identical conditions, it was not detected in suspensions or methanolic extracts of EL-52, EL-90, EL-164, or EL-222. Even concentrated extracts of these strains did not give any indication of 


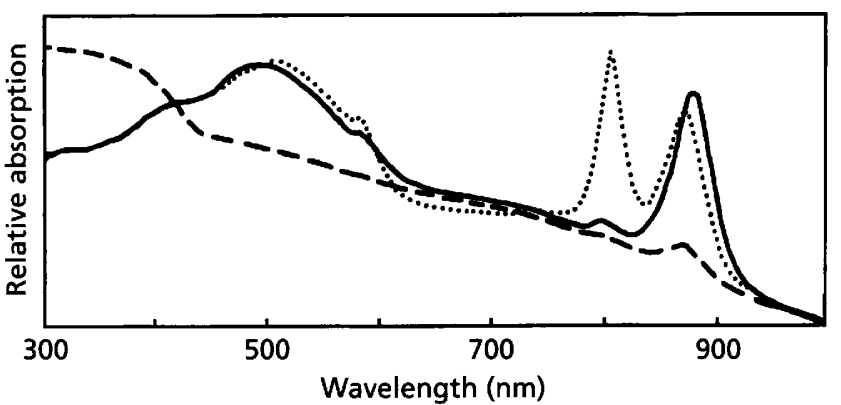

Fig. 3. In vivo absorption spectra of strains EL-172 ${ }^{\top}$ (solid line), EL-171 (dashed line) and the type strain of $R$. denitrificans (dotted line) grown aerobically in the dark.

bchl $a$ when TLC was applied. Absorbances that were characteristic of the presence of bchl $a$ were found in vivo with a large peak at $877-879 \mathrm{~nm}$ and smaller peaks at 799-802 and 589-591 nm (Fig. 3). They were similar to the maxima found in bchl $a$-containing anoxygenic phototrophs (Biebl \& Drews, 1969), but differed from the maxima of the bchl a-containing $R$. denitrificans (Fig. 3) or R. litoralis (Shiba, 1991). Other features, which are very likely due to the presence of carotenoids, were not characterized further. The absorption spectra of methanolic extracts showed a large peak at 767-769 nm and smaller ones at 605-607 and $699-700 \mathrm{~nm}$ and around $350 \mathrm{~nm}$. Unlike the situation in $R$. denitrificans, the production of bchl $a$ by EL strains was repressed in constant dim light.

The colony colours of strains EL-83 and EL-171 were white-beige to beige during the first 6 years of cultivation, indicating that these strains did not produce bchl during this period. After this time, the colony colours of EL-83 and EL-171 changed to light red, and in vivo bchl $a$ spectra had a small peak at $868-871 \mathrm{~nm}$ (Fig. 3). Five months later the colonies of EL-83 became pinkish, and thereafter, this strain produced bchl $a$ with a large peak at $878 \mathrm{~nm}$, as is the situation in EL-78 and EL-172 ${ }^{\mathrm{T}}$. Methanolic extracts of all four bchl-producing EL strains had identical absorption spectra.

Unlike $R$. denitrificans (Harashima et al., 1982), vesicular structures of intracytoplasmic membrane systems were never found in ultrathin sections of aerobically and dark grown cells of EL-172 .

The DNA $\mathrm{G}+\mathrm{C}$ base ratios were $62 \cdot 2-63 \cdot 8 \mathrm{~mol} \%$.

\section{Chemotaxonomic characteristics}

The peptidoglycan of all eight isolates contained $m$ diaminopimelic acid. The ubiquinone was Q-10. Polar lipids found in all cases were phosphatidylglycerol, phosphatidylcholine, diphosphatidylglycerol and phosphatidylethanolamine. Additionally, cells contained an unidentified aminolipid as well as one phospholipid. The fatty acid composition of the strains grown on PYGV + ASW is shown in Table 4. Their fatty acid profile was characterized by the predominance of $\mathrm{C}_{18: 1}$ and by the presence, in lower proportions, of the double-unsaturated fatty acid $\mathrm{C}_{18: 2}$, and of $\mathrm{C}_{12: 0} 2-\mathrm{OH}$ and $\mathrm{C}_{12: 1} 3-\mathrm{OH}$.

\section{Dot-blot hybridizations}

DNA probes from EL-90, EL-164, EL-171, EL-172 ${ }^{\mathrm{T}}$ or EL-222 hybridized at $75 \%$ stringency with chromosomal DNA from the other seven Ekho Lake strains but not with DNA of the four strains of $A$. heliothermus, or with $R$. denitrificans strain DSM $7001^{\mathrm{T}}$. DNA probes from $A$. heliothermus did not hybridize with chromosomal DNA from any of the eight Ekho Lake strains discussed here.

\section{$16 S$ rRNA sequence determinations and phylogenetic analyses}

Partial 16S rRNA gene sequences of the eight Ekho Lake isolates were determined by direct sequence analysis of PCR amplified products. Based on a

Table 4. Cellular fatty acid composition of EL-172 ${ }^{\top}, A$. heliothermus EL-219', and the type strains of $R$. algicola, $R$. denitrificans and $R$. litoralis

\begin{tabular}{|c|c|c|c|c|c|c|c|c|c|c|}
\hline \multirow[t]{2}{*}{ Organism } & \multicolumn{10}{|c|}{ Fatty acid composition $(\%)^{*}$} \\
\hline & $\mathrm{C}_{10: 0} 3-\mathrm{OH}$ & $\mathrm{C}_{12: 0} 2-\mathrm{OH}$ & $\mathrm{C}_{12: 1} 3-\mathrm{OH}$ & $\mathrm{C}_{14: 0} 2-\mathrm{OH}$ & $\mathbf{C}_{16: 1}$ & $\mathrm{C}_{16: 0}$ & $\mathrm{C}_{18: 2}$ & $\mathbf{C}_{18: 1}$ & $\mathrm{C}_{18: 0}$ & $\mathrm{C}_{19: 0} \mathrm{cy}$ \\
\hline EL- $172^{\mathrm{T}}+$ & - & $2 \cdot 4$ & $3 \cdot 6$ & - & $0 \cdot 8$ & $6 \cdot 2$ & $10 \cdot 6$ & $70 \cdot 2$ & $0 \cdot 8$ & $-\ddagger$ \\
\hline A. heliothermus $\dagger$ & - & - & $3 \cdot 1$ & - & 0.8 & $2 \cdot 5$ & - & $83 \cdot 2$ & $1 \cdot 0$ & $2 \cdot 4$ \\
\hline R. algicola $\$$ & - & - & - & - & - & $1 \cdot 6$ & $1 \cdot 6$ & $91 \cdot 5$ & $2 \cdot 2$ & - \\
\hline R. denitrificans $\dagger$ & $4 \cdot 2$ & - & - & - & $1 \cdot 4$ & $1 \cdot 6$ & $7 \cdot 1$ & $84 \cdot 6$ & $1 \cdot 2$ & - \\
\hline R. denitrificans§ & $1 \cdot 8$ & - & - & $2 \cdot 9$ & - & $2 \cdot 2$ & - & $87 \cdot 7$ & $2 \cdot 3$ & - \\
\hline R. litoralis§ & 1.9 & - & - & $3 \cdot 9$ & - & $1 \cdot 1$ & $1 \cdot 4$ & $88 \cdot 8$ & $1 \cdot 3$ & - \\
\hline
\end{tabular}

*Values less than $1 \%$ not shown. OH, Hydroxyl; cy, cyclopropane.

† Cells grown on PYGV + ASW.

$\$$ Sometimes present at around $1 \%$.

$\S$ Cells grown on Bacto Marine broth (Difco). 


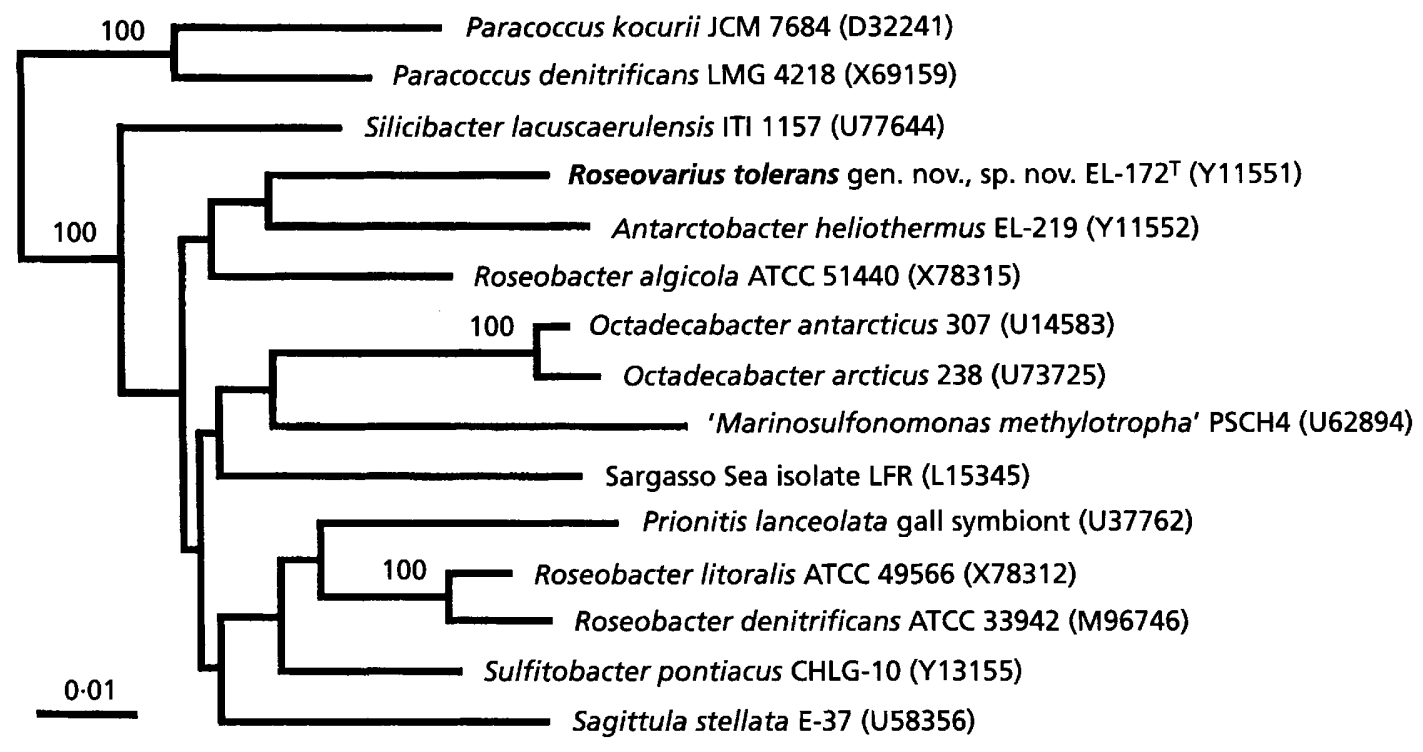

Fig. 4. Unrooted tree showing phylogenetic relationships of strain EL-172 ${ }^{\top}$ with $R$. algicola, A. heliothermus and closely related Proteobacteria. Additional sequences (listed in Methods) were used to perform the phylogenetic analyses. The tree was constructed using the neighbour-joining method ( $K_{\text {nuc }}$ values). It was based on a comparison of 1320 nucleotides. Bootstrap values, expressed as a percentage of 500 replications, are given at branching points; those below $90 \%$ are not shown.

comparative analysis of a continuous stretch of approximately 800 bases, the isolates formed a distinct group with $100 \% 16 \mathrm{~S}$ rRNA sequence similarity among each other. The almost complete 16S rRNA gene sequence ( 1320 bases) of strain EL-172 ${ }^{\mathrm{T}}$, as a representative of the group, was determined. Sequence searches of the EMBL database revealed that the newly determined sequences were related to the $\alpha$ subclass of Proteobacteria (data not shown). Strain EL-172 ${ }^{\mathrm{T}}$ displayed highest $16 \mathrm{~S}$ rRNA sequence relatedness (approximately 93-95\%) with species of the genus Roseobacter (viz. R. algicola, $R$. litoralis and $R$. denitrificans; the latter species was previously named Erythrobacter $\mathrm{sp}$. OCh 114). High sequence relatedness was also observed with $A$. heliothermus, Sagittula stellata, Octadecabacter spp. and Sulfitobacter pontiacus. Other proteobacterial species examined showed lower levels of relatedness. An unrooted tree depicting the phylogenetic relationships of the unknown Ekho Lake bacteria (as exemplified by strain EL-172 ) and its closest relatives is shown in Fig. 4. The results of treeing analyses confirmed that the Ekho Lake strain EL- $172^{\mathrm{T}}$ was phylogenetically most closely related to Roseobacter species and their near relatives, and that isolate EL-172 ${ }^{\mathrm{T}}$ formed a distinct subline.

\section{DISCUSSION}

The six different enrichment procedures used for Ekho Lake samples yielded eight nearly identical bacterial isolates, although these came from depths of 6-22 m. Apart from differences in the sample salinity (63$142 \%$ ), the properties of these original samples were rather similar (Table 1). It is, therefore, possible that this new species, represented by the eight isolates, is widely distributed in different layers of the lake. Chromosomal DNA of all eight isolates hybridized with DNA probes of strains EL-90, EL-164, EL-171, EL-172 ${ }^{\mathrm{T}}$ and EL-222 (at $75 \%$ stringency), and sequencing of 16S rRNA genes confirmed that the isolates were genetically very similar and that they were all members of a distinct taxon within the $\alpha$-3-subclass of the Proteobacteria. The eight isolates displayed very similar morphologies, but there were some minor physiological differences. All strains tolerated wide ranges of temperature, $\mathrm{ASW}, \mathrm{NaCl}$ and $\mathrm{pH}$. Four of the eight strains produced bchl $a$. Unlike $R$. denitrificans, bchl $a$ production was repressed by constant dim light; in vivo characteristic absorption bands were measured at 799-802 and 877-879 nm.

Production of bchl $a$ by two strains which had been bchl $a$-free during most of the cultivation time was observed. Possibly the bchl $a$ genes of these EL strains were silent, but conditions for their induction were not detected. These results indicated likewise that $E$. ursincola and $B$. natatoria (see Introduction) could be members of at least the same genus. The data presented here show that the presence of bchl $a$ production may not be a very significant characteristic for taxonomic purposes.

The eight EL strains were nearly identical based on the results of the chemotaxonomic tests used. Taken together, the combination of respiratory lipoquinones, fatty acids and polar lipid data indicated that these strains belonged to a group of organisms (at the genus or family rank) within the $\alpha$-subclass of the Proteobacteria (Labrenz et al., 1998). 
$\mathrm{C}_{18: 1}$ is the characteristic fatty acid within the $\alpha$ subclass of the Proteobacteria and $\mathrm{C}_{18: 2}$, in most cases, was characteristic of the eight isolates and Roseobacter spp. The strains were differentiated by fatty acids present in lower proportions, such as $\mathrm{C}_{12: 0} 2-\mathrm{OH}$ and $\mathrm{C}_{12: 1} 3-\mathrm{OH}$ for the eight isolates, or $\mathrm{C}_{10: 0} 3-\mathrm{OH}$ and $\mathrm{C}_{14: 0} 2-\mathrm{OH}$ for $R$. denitrificans and $R$. litoralis. When grown on Bacto Marine broth, $R$. algicola did not contain any of the characteristic fatty acids observed at lower proportions in $R$. denitrificans and $R$. litoralis. However, the polar lipid and the utilization patterns of carbon sources of the eight strains and $R$. algicola (as detected in the BIOLOG system; Table 3) were nearly identical; these patterns were quite different from those of $R$. denitrificans, $R$. litoralis or $A$. heliothermus. In addition, the $\mathrm{G}+\mathrm{C}$ content of $R$. algicola $(64 \cdot 0$ $65.0 \mathrm{~mol} \%$ ) was more similar to that of the eight strains $(62 \cdot 2-63 \cdot 8 \mathrm{~mol} \%)$ than to that of the other Roseobacter species $(56 \cdot 3-60 \cdot 1 \mathrm{~mol} \%)$. Comparative 16S rRNA gene sequencing, chemotaxonomic, biochemical and physiological studies clearly show the close relationship of $R$. denitrificans and $R$. litoralis. On the other hand, $R$. algicola appears to be more related to, albeit different from, the eight isolates, as shown by physiological (Table 2 ) and fatty acid data (Table 4).

Comparative 16S rRNA gene sequencing showed that the eight bacteria from Ekho Lake, as exemplified by EL-172 ${ }^{\mathrm{T}}$, were members of the $\alpha$-subclass of Proteobacteria and were specifically associated with the Roseobacter cluster of organisms which also included Antarctobacter and 'Marinosulfonomonas' (Holmes et al., 1997), the Prionitis gall symbiont, Octadecabacter (Gosink et al., 1997), Roseobacter, Sagittula (Gonzalez et al., 1997), Sulfitobacter (Sorokin, 1995), and an uncharacterized Sargasso Sea isolate. Sequence divergence values of $>5 \%(4.7 \%$ to $R$. algicola $)$ showed that the eight isolates were phylogenetically distinct from all currently recognized members of the Proteobacteria. Furthermore, bootstrap resampling showed the organisms from Ekho Lake did not possess a particularly significant phylogenetic affinity with any individual species within the above-mentioned Roseobacter cluster (Fig. 4). It is evident from the treeing analyses that the genus Roseobacter, as currently recognized, is interdispersed with several other taxa. Based on the chemotaxonomic and biochemical data presented here it is concluded that, to fulfil the criteria of being a monophyletic group, the genus Roseobacter should be restricted to the species $R$. litoralis and $R$. denitrificans. However, $R$. algicola should be a member of a new and different taxon, to be described in the future. On the basis of the genotypic (16S rDNA sequence) and phenotypic (biochemical, chemotaxonomic, physiological) data presented here (Table 2), the eight Antarctic strains are distinctive, not only from the more distantly related species (i.e. $R$. litoralis, $R$. denitrificans), but they can also be distinguished from more closely related species (i.e. $R$. algicola). Thus, it is concluded that the eight Ekho Lake isolates are representatives of a new and distinctive taxon, for which the name Roseovarius tolerans gen. nov., sp. nov. is proposed.

\section{Description of Roseovarius gen. nov.}

Roseovarius (Ro.se.o.va'ri.us. L. adj. roseus rosecoloured; L. adj. varius diverse, varied; M.L. masc. $\mathrm{n}$ Roseovarius the varying rose-coloured one).

Gram-negative rods with one or both cell poles pointed, multiplying by monopolar growth, i.e. by a budding process. Daughter cells may be motile. The cells may contain poly- $\beta$-hydroxybutyrate. They do not form spores. On PYGV + ASW or R2A + ASW media, colonies are smooth, convex and variously coloured. Bchl $a$ may be produced. The temperature range for growth is $<3$ to $43.5^{\circ} \mathrm{C}$. The cells have an absolute requirement for $\mathrm{Na}^{+}$; they grow in $<1.0$ to $10.0 \% \mathrm{NaCl}$. In the presence of ASW, they grow at $<10$ to $>150 \%$. The $\mathrm{pH}$ tolerance range is 5.3 to $>9$. Strictly aerobic, non-fermentative heterotrophs. No growth is observed on glucose anaerobically in the absence of nitrate. Cells do not grow photoautotrophically with $\mathrm{H}_{2} / \mathrm{CO}_{2}(80: 20)$ or photoorganotrophically with acetate or glutamate. The cells exhibit peroxidase, catalase and weak cytochrome oxidase activity. The following polar lipids are present: diphosphatidylglycerol, phosphatidylglycerol, phosphatidylcholine, phosphatidylethanolamine, as well as an unknown phospholipid and an aminolipid. The dominant fatty acid is $\mathrm{C}_{18: 1}$; other characteristic fatty acids are $\mathrm{C}_{18: 2}, \mathrm{C}_{12: 0} 2-\mathrm{OH}, \mathrm{C}_{12: 1} 3-\mathrm{OH}, \mathrm{C}_{16: 1}, \mathrm{C}_{16: 0}$ and $\mathrm{C}_{18: 0}$. The major respiratory quinone is $\mathrm{Q}-10$. The strains were originally obtained from water samples from Ekho Lake, Antarctica (Vestfold Hills). The type species for the genus is Roseovarius tolerans.

\section{Roseovarius tolerans sp. nov.}

Roseovarius tolerans (tol'e.rans. L. part. adj. tolerans bearing/tolerating, as the bacterium endures stress conditions).

Cell sizes vary $(0 \cdot 7-1 \cdot 0 \times 1 \cdot 1-2 \cdot 2 \mu \mathrm{m})$, with a mean size of $0.74-0.83 \times 1.34-1.94 \mu \mathrm{m}$. On PYGV + ASW or R2A + ASW media, colonies of individual strains are smooth and convex and red, pinkish, beige to red, beige or whitish-beige. Optimal growth occurs at $8-33.5^{\circ} \mathrm{C}$ with salt concentrations of $1.0-8.0 \% \mathrm{NaCl}$ or $10-130 \%$ ASW. The optimum pH is 5.9->9.0. Bchl $a$ may be produced with a large in vivo absorption band at $877-879 \mathrm{~nm}$ and smaller ones at $589-591$ and $799-802 \mathrm{~nm}$. The production of bchl $a$ is repressed by constant dim light. The isolates have a weak requirement for thiamin and nicotinic acid. The requirement for vitamin $B_{12}$ is variable, and cells are 
stimulated by biotin but do not need pantothenate. Alginate, gelatin and starch are not hydrolysed, Tween 80 and DNA are only hydrolysed by some strains. Growth occurs on acetate, pyruvate, malate, succinate, butyrate or glutamate, but not on citrate, methanesulfonic acid, methanol or $\alpha$-D-glucose. In the absence of any added nitrogen compounds, the cells grow slightly on acetate, pyruvate, succinate, malate and butyrate. Glutamate is used with and without an additional source of combined nitrogen. Cells are susceptible to chloramphenicol, streptomycin, penicillin $G$ and tetracycline, but not to polymyxin B. Nitrate is not reduced, $\mathrm{H}_{2} \mathrm{~S}$ and indole are not produced. The $\mathrm{G}+\mathrm{C}$ content is $62 \cdot 2-63 \cdot 8 \mathrm{~mol} \%$. Chemotaxonomic properties and other characteristics are as for the genus. The type strain, Roseovarius tolerans EL-172 ${ }^{\mathrm{T}}$, has been deposited in the Deutsche Sammlung von Mikroorganismen und Zellkulturen under accession number DSM $11457^{\mathrm{T}}$. Additional isolates of Roseovarius tolerans are EL-222 (=DSM 11463), EL-52, EL-78, EL-83, EL-90, EL-164 and EL171.

\section{ACKNOWLEDGEMENTS}

We gratefully acknowledge the skilful technical assistance of B. Hoffmann, M. Beese, R. Emcke and J. Buschdorf. J. Siebert (Hamburg) helped with the Antarctic field work and H. Völker (Kiel) with electron microscopy. We especially want to thank the Australian Antarctic Division (Kingston, Tasmania) for supporting two summer visits to Davis Station and the Vestfold Hills (Antarctica). H. R. Burton (Australian Antarctic Division) and Professor T. A. McMeekin (Univ. of Tasmania, Hobart) supported this research with much practical help and generous hospitality. We thank the Deutsche Forschungsgemeinschaft (DFG) for grants Hi 68/16-3, Hi 68/19-3 and $\mathrm{Hi} \mathrm{68/25-1} \mathrm{and} \mathrm{25-2,} \mathrm{and}$ the European Union for grants CT 93-0194 and CT 93-0119.

\section{REFERENCES}

Biebl, H. \& Drews, G. (1969). Das in-vivo-Spektrum als taxonomisches Merkmal bei Untersuchungen zur Verbreitung von Athiorhodaceae. Zentbl Bakteriol 123, 425-452.

Bradford, M. M. (1976). A rapid and sensitive method for the quantitation of microgram quantities of protein utilizing the principle of protein-dye binding. Anal Biochem 72, 248-254.

Cohen-Bazire, G., Sistrom, W. R. \& Stanier, R. Y. (1957). Kinetic studies of pigment synthesis by non-sulfur purple bacteria. $J$ Cell Physiol 49, 25-68.

Devereux, J., Haeberli, P. \& Smithies, O. (1984). A comprehensive set of sequence analysis programs for the VAX. Nucleic Acids Res 12, 387-395.

Drews, G. (1974). Mikrobiologisches Praktikum, 2nd edn. Berlin: Springer.

Felsenstein, J. (1989). PHYLIP - phylogeny inference package (version 3.2). Cladistics 5, 164-166.

Franzmann, P. D., Burton, H. R. \& McMeekin, T. A. (1987). Halomonas subglaciescola, a new species of halotolerant bacteria isolated from Antarctica. Int J Syst Bacteriol 37, 27-34.

Fuerst, J. A., Hawkins, J. A., Holmes, A., Sly, L. I., Moore, C. J. \& Stackebrandt, E. (1993). Porphyrobacter neustonensis gen. nov., sp. nov., an aerobic bacteriochlorophyll-synthesizing budding bacterium from freshwater. Int J Syst Bacteriol 43, 125-134.

Gonzalez, J. M., Mayer, F., Moran, M. A., Hodson, R. E. \& Whitman, W. B. (1997). Sagittula stellata gen. nov., sp. nov., a lignin-transforming bacterium from a coastal environment. Int $J$ Syst Bacteriol 47, 773-780.

Gosink, J. J., Herwig, R. P. \& Staley, J. T. (1997). Octadecabacter arcticus gen. nov., sp. nov., and $O$. antarcticus, sp. nov., nonpigmented, psychrophilic gas vacuolate bacteria from polar sea ice and water. Syst Appl Microbiol 20, 356-365.

Groth, I., Schumann, P., Weiss, N., Martin, K. \& Rainey, F. A. (1996). Agrococcus jenensis gen. nov., sp. nov., a new genus of actinomycetes with diaminobutyric acid in the cell wall. Int $J$ Syst Bacteriol 46, 234-239.

Harashima, K., Nakagawa, M. \& Murata, N. (1982). Photochemical activities of bacteriochlorophyll in aerobically grown cells of aerobic heterotrophs, Erythrobacter species (OCh 114) and Erythrobacter longus (OCh 101). Plant Cell Physiol 23, 185-193.

Hirsch, P. (1974). Budding bacteria. Annu Rev Microbiol 28, $391-444$.

Holmes, A. J., Kelly, D. P., Baker, S. C., Thompson, A. S., Marco, P. D., Kenna, E. M. \& Murrell, J. C. (1997). Methylosulfonomonas methylovora gen. nov., sp. nov., and Marinosulfonomonas methylotropha gen. nov., sp. nov.: novel methylotrophs able to grow on methanesulfonic acid. Arch Microbiol 167, 46-53.

Hudson, R. A., Thompson, D. E. \& Collins, M. D. (1993). Genetic interrelationships of saccharolytic Clostridium botulinum types $\mathrm{B}, \mathrm{E}$ and $\mathrm{F}$ and related clostridia by small-subunit rRNA gene sequences. FEMS Microbiol Lett 108, 103-110.

James, S. R., Burton, H. R., McMeekin, T. A. \& Mancuso, C. A. (1994). Seasonal abundance of Halomonas meridiana, Halomonas subglaciescola, Flavobacterium gondwanense, and Flavobacterium salegens in four antarctic lakes. Antarct Sci 6, 325-332.

Jukes, T. H. \& Cantor, C. R. (1969). Evolution of protein molecules. In Mammalian Protein Metabolism, pp. 21-132. Edited by H. N. Munro. New York: Academic Press.

Kreisel, H. \& Schauer, F. (1987). Methoden des mykologischen Laboratoriums. Stuttgart: Gustav Fischer.

Labrenz, M., Collins, M. D., Lawson, P. A., Tindall, B. J., Braker, G. \& Hirsch, P. (1998). Antarctobacter heliothermus gen. nov., sp. nov., a budding bacterium from hypersaline and heliothermal Ekho Lake. Int J Syst Bacteriol 48, 1363-1372.

Lafay, B., Ruimy, R., Rausch de Traubenberg, C., Breittmayer, V., Gauthier, M. J. \& Christen, R. (1995). Roseobacter algicola $\mathrm{sp.}$ nov., a new marine bacterium isolated from the phycosphere of the toxin-producing dinoflagellate Prorocentrum lima. Int J Syst Bacteriol 45, 290-296.

Lyman, J. \& Fleming, R. H. (1940). Composition of sea water. $J$ Mar Res 3, 134-146.

Mesbah, M., Premachandran, U. \& Whitman, W. B. (1989). Precise measurement of the $\mathrm{G}+\mathrm{C}$ content of deoxyribonucleic acid by high-performance liquid chromatography. Int J Syst Bacteriol 39, 159-167.

Pearson, W. R. \& Lipman, D. J. (1988). Improved tools for biological sequence comparison. Proc Natl Acad Sci USA 85, 2444-2448.

Pfennig, N. \& Wagener, S. (1986). An improved method of preparing wet mounds for photomicrographs of microorganisms. J Microbiol Methods 4, 303-306.

Rhuland, L. E., Work, E., Denman, R. F. \& Hoare, D. S. (1955). The 
behavior of the isomers of $\alpha, \varepsilon$-diaminopimelic acid on paper chromatograms. J Am Chem Soc 77, $4844-4846$.

Saitou, N. \& Nei, M. (1987). The neighbor-joining method: a new method for reconstructing phylogenetic trees. Mol Biol Evol 4, 406-425.

Sambrook, J., Fritsch, E. F. \& Maniatis, T. (1989). Molecular Cloning : a Laboratory Manual, 2nd edn. Cold Spring Harbor, NY: Cold Spring Harbor Laboratory.

Sasser, M. (1990). Identification of bacteria by gas chromatography of cellular fatty acids. USFCC Newsl 20, 1-6.

Shiba, T. (1991). Roseobacter litoralis gen. nov., sp. nov., and Roseobacter denitrificans sp. nov., aerobic pink-pigmented bacteria which contain bacteriochlorophyll a. Syst Appl Microbiol 14, 140-145.

Shiba, T. \& Simidu, U. (1982). Erythrobacter longus gen. nov., sp. nov., an aerobic bacterium which contains bacteriochlorophyll a. Int J Syst Bacteriol 32, 211-217.

Skerman, V. B. D. (1967). A Guide to the Identification of the Genera of Bacteria, 2nd edn. Baltimore: Williams \& Wilkins.

Smibert, R. M. \& Krieg, N. R. (1994). Phenotypic characterization. In Methods for General and Molecular Bacteriology, pp. 607-654. Edited by P. Gerhardt, R. G. E. Murray, W. A. Wood \& N. R. Krieg. Washington, DC: American Society for Microbiology.

Sorokin, D. Y. (1995). Sulfitobacter pontiacus gen. nov., sp. nov.
- a new heterotrophic bacterium from the Black Sea, specialized on sulfite oxidation. Microbiology 64, 295-305.

Staley, J. T. (1968). Prosthecomicrobium and Ancalomicrobium, new prosthecate fresh water bacteria. J Bacteriol 95, 1921-1944.

Tindall, B. J. (1990a). A comparative study of the lipid composition of Halobacterium saccharovorum from various sources. Syst Appl Microbiol 13, 128-130.

Tindall, B. J. (1990b). Lipid composition of Halobacterium lacusprofundi. FEMS Microbiol Lett 66, 199-202.

Van Ert, M. \& Staley, J. T. (1971). Gas-vacuolated strains of Microcyclus aquaticus. J Microbiol 108, 236-240.

Woese, C. R. (1987). Bacterial evolution. Microbiol Rev 51, 221-271.

Yurkov, V., Stackebrandt, E., Holmes, A. \& 7 other authors (1994). Phylogenetic positions of novel aerobic, bacteriochlorophyll $a$ containing bacteria and description of Roseococcus thiosulfatophilus gen. nov., sp. nov., Erythromicrobium ramosum gen. nov., sp. nov., and Erythrobacter litoralis sp. nov. Int J Syst Bacteriol 44, 427-434.

Yurkov, V., Stackebrandt, E., Buss, O., Vermeglio, A., Gorlenko, V. \& Beatty, J. T. (1997). Reorganization of the genus Erythromicrobium: description of 'Erythromicrobium sibiricum' as Sandaracinobacter sibiricus gen. nov., sp. nov., and of 'Erythromicrobium ursincola' as Erythromonas ursincola gen. nov., sp. nov. Int J Syst Bacteriol 47, 1172-1178. 